\title{
Spatial distribution and risk factors of Brucellosis in Iberian wild ungulates
}

\author{
Pilar M Muñoz ${ }^{1,2}$, Mariana Boadella ${ }^{3 *}$, Maricruz Arnal ${ }^{4}$, María J de Miguel ${ }^{1}$, Miguel Revilla ${ }^{4}$, David Martínez ${ }^{4}$, \\ Joaquín Vicente ${ }^{3}$, Pelayo Acevedo ${ }^{5}$, Álvaro Oleaga ${ }^{3,6}$, Francisco Ruiz-Fons $^{7}$, Clara M Marín ${ }^{1}$, José M Prieto $^{6}$, \\ José de la Fuente ${ }^{3,8}$, Marta Barral ${ }^{7}$, Montserrat Barberán ${ }^{4}$, Daniel Fernández de Luco ${ }^{4}$, José M Blasco 1 , \\ Christian Gortázar ${ }^{3}$
}

\begin{abstract}
Background: The role of wildlife as a brucellosis reservoir for humans and domestic livestock remains to be properly established. The aim of this work was to determine the aetiology, apparent prevalence, spatial distribution and risk factors for brucellosis transmission in several Iberian wild ungulates.

Methods: A multi-species indirect immunosorbent assay (iELISA) using Brucella S-LPS antigen was developed. In several regions having brucellosis in livestock, individual serum samples were taken between 1999 and 2009 from 2,579 wild bovids, 6,448 wild cervids and4,454 Eurasian wild boar (Sus scrofa), and tested to assess brucellosis apparent prevalence. Strains isolated from wild boar were characterized to identify the presence of markers shared with the strains isolated from domestic pigs.

Results: Mean apparent prevalence below $0.5 \%$ was identified in chamois (Rupicapra pyrenaica), Iberian wild goat (Capra pyrenaica), and red deer (Cervus elaphus). Roe deer (Capreolus capreolus), fallow deer (Dama dama), mouflon (Ovis aries) and Barbary sheep (Ammotragus lervia) tested were seronegative. Only one red deer and one Iberian wild goat resulted positive in culture, isolating B. abortus biovar 1 and B. melitensis biovar 1, respectively. Apparent prevalence in wild boar ranged from $25 \%$ to $46 \%$ in the different regions studied, with the highest figures detected in South-Central Spain. The probability of wild boar being positive in the iELISA was also affected by age, age-by-sex interaction, sampling month, and the density of outdoor domestic pigs. A total of 104 bacterial isolates were obtained from wild boar, being all identified as B. suis biovar 2. DNA polymorphisms were similar to those found in domestic pigs.
\end{abstract}

Conclusions: In conclusion, brucellosis in wild boar is widespread in the Iberian Peninsula, thus representing an important threat for domestic pigs. By contrast, wild ruminants were not identified as a significant brucellosis reservoir for livestock.

\section{Background}

Brucellosis is an infectious disease caused by bacteria of the genus Brucella, characterized by abortion and infertility in several mammal species, and being considered one of the most important zoonosis worldwide [1]. Brucella melitensis, followed by Brucella abortus and Brucella suis, are the main species involved in the infection of human beings, thus being the main target of eradication campaigns.

\footnotetext{
* Correspondence: mariana.boadella@uclm.es

${ }^{3}$ IREC (CSIC-UCLM-JCCM). Ronda de Toledo s/n, 13071 Ciudad Real, Spain
}

With very few exceptions, $B$. suis infection in both humans and pigs remains an important problem in most countries. B. suis biovar 2 is the main responsible of brucellosis in pigs in Europe. Despite having been isolated from human beings [2], this biovar 2 seems to be less pathogenic for humans than the biovars 1 and 3 [3]. Other Brucella species have been isolated in rodents, terrestrial carnivores, and sea mammals, but the relevance of these Brucella species for livestock and human beings is quite limited [3-5].

Wild animals are often at risk as a consequence of contacts with infected livestock, particularly in extensive 
breeding systems. In addition to the $B$. abortus infection specific problem shared by cattle, bison (Bison bison) and elk (Cervus elaphus) in limited territories of the USA (see below), some sporadic cases have been reported in wild bovids, such as ibex (Capra ibex) and chamois (Rupicapra sp.) in the EU [6,7]. Although wild ruminants have been suggested to hold brucellosis and eventually originate spillback to domestic animals or infection in humans, the most extended opinion is that these wild animals are occasional victims of brucellosis transmitted from infected livestock, rather than a true reservoir of the disease for domestic animals [8]. In fact, only limited cases of brucellosis have been reported in these free-living animals $[3,9,10]$, and only weak evidence for a direct relationship between brucellosis apparent prevalence and wild ruminant population size/ density has been found (e.g. [11] and references therein). However, the risk can be high in overabundant wildlife populations in contact with infected livestock and when artificial management increases aggregation $[8,11]$. In the Greater Yellowstone Ecosystem in the USA, winter feeding of elk and bison contributes to maintain valuable wildlife populations and avoid contacts between $B$. abortus infected wildlife and cattle, but significantly increases the intra-specific transmission risk [12]. Modelling of observational data has shown that brucellosis prevalence in elk correlates with the timing of the winter feeding season [13]. This underlines that human dimension issues are fundamental to successful management of wildlife diseases [11].

Brucellosis caused by B. suis biovar 2 is frequently reported in the Eurasian wild boar (Sus scrofa) and the European brown hare (Lepus europaeus), and apparent prevalence ranging from 8 to $32 \%$ has been reported in wild boar in the EU [10,14-18]. It is accepted that both species play a relevant role as a brucellosis reservoir for domestic pigs, even under natural environmental conditions $[3,15,19]$. In fact, both wildlife species have been directly involved in the transmission of infection to domestic pigs reared in outdoor farms [10]. Outside the EU, feral pigs may maintain $B$. suis biovars 1 and 3, being a potential source of infection to both domestic pigs and human beings [20].

Only limited information on wildlife brucellosis is available in the Iberian Peninsula. Regarding wild ruminants, brucellosis has not been detected in limited studies conducted on Barbary sheep (Ammotragus lervia) [21], Cantabrian chamois (Rupicapra pyrenaica parva) [22] and mouflon (Ovis aries) [23]. In contrast, several cases of infections induced by $B$. suis biovar 2, have been reported in wild boar [24] and European brown hares [25]. Wild ungulates are currently expanding and increasing in density in the whole Iberian Peninsula [26], as well as the artificial management of these wild species including fencing, feeding and translocation, then increasing the risk of infectious disease transmission [27].

The availability of accurate and validated diagnostic tests is of paramount importance to properly assessing the prevalence of brucellosis in wildlife [28]. In this work we developed a multispecies iELISA to determine brucellosis apparent prevalence in several Iberian wild ungulate species, and determined spatial distribution and risk factors associated with brucellosis. We hypothesised that: (1) free-living wild ruminants would not show significant infection with Brucella species; (2) wild boar, conversely, would show infection with B. suis biovar 2, constituting a potential hazard for domestic pigs; and (3) apparent prevalence would vary with environmental, population and individual risk factors such as artificial management.

\section{Methods}

\section{Study area}

The study area was the Iberian Peninsula in the southwestern European Union. This includes a variety of habitats and climates, which can be simplified into 5 different Bio-regions in the mainland, as defined in the Spanish Wildlife Disease Surveillance Scheme (Internal report to the Spanish Ministry of Agriculture, MARM and spatial aggregation of wildlife. 2008). Table 1 summarises the most relevant characteristics of each Bioregion.

\section{Animal sampling procedures}

The number of samples obtained by species and study region is summarised in Table 2. Sampling was opportunistic and biased towards the hunting season (October to February in most species, and summer in chamois and roe deer), and took place from 1999/2000 to 2008/ 2009. The total number of wild ungulates sampled was 13,481, including 2,579 bovids (Barbary sheep, chamois, Iberian wild goat and mouflon), 6,448 cervids (roe deer, red deer and fallow deer) - see Table 2 for the precise numbers in each animal species-, and 4,454 wild boar. Samples were collected from hunter-harvested animals. Blood was drawn from the heart or the thoracic cavity during field necropsies, then the serum (usually haemolysed) was collected after centrifugation and kept frozen at $-20^{\circ} \mathrm{C}$ until analysed. Whenever possible, cranial and iliac lymph nodes, spleen and sexual organs were collected and stored at $-20^{\circ} \mathrm{C}$ for microbiological analyses. The number of samples from the different animal species submitted to microbiological studies is shown in Table 2.

Age-classes of biological meaning were defined. Based on tooth eruption patterns, wild ruminants were classified as fawns (first year of life), yearlings (second year of life), 


\section{Table 1 Characteristics of the Bio-regions of the Iberian Peninsula included in the study area}

\begin{tabular}{|c|c|c|c|}
\hline Bio-region & Environment & Wildlife & Sampling site characteristics \\
\hline 1.- Atlantic & $\begin{array}{l}\text { Atlantic climate with high precipitation. } \\
\text { Pastures and deciduous woodlands. } \\
\text { Mountain habitats. Almost no fencing of } \\
\text { wildlife habitats. }\end{array}$ & $\begin{array}{l}\text { Wild boar and roe deer abundant. Locally } \\
\text { red deer abundant. Chamois at high } \\
\text { altitudes (Cantabrian Mts.). }\end{array}$ & $\begin{array}{l}\mathrm{N}=76 . \text { Woodlands: } 62 \% \text {; Agricultural lands: } \\
33 \% \text {. Altitude (in m): mean } 452 \text { (range } 0- \\
\text { 2032). Mean annual precipitations (in mm): } \\
\text { 1284. Mean annual temperature (in }{ }^{\circ} \mathrm{C} \text { ): } 12\end{array}$ \\
\hline $\begin{array}{l}\text { 2.- Northern- } \\
\text { Plateau }\end{array}$ & $\begin{array}{l}\text { Continental Mediterranean climate. Dry, } \\
\text { hot summers, dry, cold winters. Open, } \\
\text { cereal landscapes with pine or oak } \\
\text { woodlands, limited to the north by } \\
\text { mountains. Little fencing. }\end{array}$ & $\begin{array}{l}\text { Ungulates expanding and locally abundant. } \\
\text { Chamois limited to high altitudes in the } \\
\text { Pyrenees. Locally ibex and fallow deer. }\end{array}$ & $\begin{array}{l}\mathrm{N}=98 . \text { Woodlands: } 68 \% \text {; Agricultural lands: } \\
30 \% \text {. Altitude (in m): mean } 987 \text { (range } 67- \\
\text { 3314). Mean annual precipitations (in mm): } \\
\text { 808. Mean annual temperature (in }{ }^{\circ} \mathrm{C} \text { ): } 10.5\end{array}$ \\
\hline $\begin{array}{l}\text { 3.- South- } \\
\text { Central }\end{array}$ & $\begin{array}{l}\text { Continental Thermo Mediterranean } \\
\text { climate. Pastures and crops with } \\
\text { interspersed vegetation, sometimes } \\
\text { forming savannah-like structures. Low } \\
\text { altitude mountains with scrubland. } \\
\text { Frequent fencing. }\end{array}$ & $\begin{array}{l}\text { Wild boar and red deer often at high } \\
\text { density; feeding and watering. Locally } \\
\text { abundant fallow deer and Iberian ibex, and } \\
\text { introduced wild bovids. }\end{array}$ & $\begin{array}{l}\mathrm{N}=72 \text {. Woodlands: } 68 \% \text {; Agricultural lands: } \\
\text { 29\%. Altitude (in m): mean } 705 \text { (range } 47- \\
\text { 2321). Mean annual precipitations (in mm): } \\
\text { 605. Mean annual temperature (in }{ }^{\circ} \mathrm{C} \text { ): } 14.5\end{array}$ \\
\hline $\begin{array}{l}\text { 4.-Interior } \\
\text { Mountains }\end{array}$ & $\begin{array}{l}\text { Severe Continental Mediterranean } \\
\text { climate. Limestone mountain and high- } \\
\text { plateau habitats with cereal crops, } \\
\text { pastures, and pine and oak woodlands. } \\
\text { Little fencing. }\end{array}$ & $\begin{array}{l}\text { Wild boar, roe deer, and ibex widely } \\
\text { distributed but usually at moderate } \\
\text { abundance. Locally abundant red deer. }\end{array}$ & $\begin{array}{l}\mathrm{N}=22 \text {. Woodlands: } 71 \% \text {; Agricultural lands: } \\
\text { 29\%. Altitude (in m): mean } 1178 \text { (range } 248 \text { - } \\
\text { 1932). Mean annual precipitations (in mm): } \\
\text { 568. Mean annual temperature (in }{ }^{\circ} \mathrm{C} \text { ): } 11.3\end{array}$ \\
\hline $\begin{array}{l}\text { 5.- South } \\
\text { and East } \\
\text { Coast }\end{array}$ & $\begin{array}{l}\text { Coastal Thermo Mediterranean climate; } \\
\text { arid in the central portion. Few well } \\
\text { preserved wildlife habitats (mountains). } \\
\text { Little fencing. }\end{array}$ & $\begin{array}{l}\text { Wild boar abundant in the northern and } \\
\text { southern ends. Other ungulates locally } \\
\text { abundant. }\end{array}$ & $\begin{array}{l}\mathrm{N}=7 . \text { Woodlands: } 48 \% \text {; Agricultural lands: } \\
23 \% \text {. Altitude (in m): mean } 190 \text { (range } 0- \\
\text { 1238). Mean annual precipitations (in mm): } \\
\text { 720. Mean annual temperature (in }{ }^{\circ} \mathrm{C} \text { ): } 15.7\end{array}$ \\
\hline
\end{tabular}

Table 2 Sample size by host species and Bio-region studied, apparent prevalence obtained, and Brucella culture results in Iberian wild ungulate species.

\begin{tabular}{|c|c|c|c|c|c|c|c|c|c|c|}
\hline \multirow{2}{*}{$\begin{array}{l}\text { Common } \\
\text { name }\end{array}$} & \multirow[t]{2}{*}{ Latin name } & \multicolumn{6}{|c|}{ Serum samples by region } & \multirow{2}{*}{$\begin{array}{l}\text { Mean prevalence } \\
(95 \% \mathrm{Cl})\end{array}$} & \multirow{2}{*}{$\begin{array}{l}\text { Samples submitted for } \\
\text { culture }\end{array}$} & \multirow{2}{*}{$\begin{array}{c}\text { Nr. of isolates (species } \\
\text { and biovar) }\end{array}$} \\
\hline & & 1 & 2 & 3 & 4 & 5 & Total & & & \\
\hline $\begin{array}{l}\text { Barbary } \\
\text { sheep }\end{array}$ & $\begin{array}{l}\text { Ammotragus } \\
\text { lervia }\end{array}$ & 0 & 0 & 8 & 0 & 0 & 8 & $0(0-36)$ & 0 & \\
\hline Mouflon & Ovis aries & 0 & 0 & 75 & 0 & 0 & 75 & $0(0-5)$ & 0 & \\
\hline $\begin{array}{l}\text { Iberian wild } \\
\text { goat }^{1}\end{array}$ & $\begin{array}{l}\text { Capra } \\
\text { pyrenaica }\end{array}$ & 0 & 41 & 2 & 1042 & 1 & 1086 & $0.1(0-0.6)$ & $1^{2}$ & 1 (B. melitensis biovar 1) \\
\hline Chamois $^{3}$ & $\begin{array}{l}\text { Rupicapra } \\
\text { pyrenaica }\end{array}$ & 57 & 1353 & 0 & 0 & 0 & 1410 & $0.8(0.4-1.4)$ & 11 & \\
\hline Roe deer & $\begin{array}{l}\text { Capreolus } \\
\text { capreolus }\end{array}$ & 77 & 152 & 5 & 9 & 42 & 285 & $0(0-1)$ & 0 & \\
\hline Fallow deer & Dama dama & 92 & 107 & 47 & 32 & 64 & 342 & $0(0-1)$ & 0 & \\
\hline Red deer & Cervus elaphus & 452 & 1591 & 2378 & 932 & 468 & 5821 & $0.4(0.3-0.6)$ & $81^{4}$ & 1 (B. abortus biovar 1 ) \\
\hline Wild boar & Sus scrofa & 658 & 1920 & 1499 & 132 & 245 & 4454 & $33(31.6-34.4)$ & $589^{5}$ & 104 (B. suis biovar 2) \\
\hline TOTAL & & 1336 & 5164 & 4014 & 2147 & 820 & 13481 & & 682 & 106 \\
\hline
\end{tabular}

${ }^{1}$ Includes mainly the Mediterranean subspecies Capra pyrenaica hispanica. ${ }^{2}$ All animals were sampled randomly during hunting or at game farms but for the ibex tissues submitted for culture, which came from a clinical case with suspected brucellosis. ${ }^{3}$ Cantabrian chamois (Rupicapra pyrenaica parva) in Bio-region 1 and Pyrenean chamois (R. p. pyrenaica) in Bio-region 2. ${ }^{4}$ Thirty-one out of these 81 samples came from iELISA-positive animals and 50 from iELISA-negative ones. ${ }^{5}$ A total of 539 out of these 589 samples were from iELISA-positive animals and 50 from iELISA-negative ones.

juveniles (third to fourth year of life), and adults (fifth year of life onwards). Wild boar less than 7 months old were classified as piglets, between 7 and 12 months were classified as juveniles, those between 12 and 24 months as sub-adults, and those over 2 years as adults [29]. Sex was known in 5,683 wild ruminants, and age-classes in 4,065 . For wild boar, sex was known in 2,688 animals and age in 2,419 .

\section{Serological studies}

A multi-species indirect enzyme immunoassay (iELISA) was developed and validated to assess brucellosis apparent prevalence. Briefly, a phenol-water smooth lipopolysaccharide (S-LPS) rich extract from B. melitensis 16M was obtained as described elsewhere [30]. Standard 96well polystyrene plates (Maxisorp Nunc A/S, Roskilde, Denmark) were coated with $100 \mu \mathrm{l}$ of an antigen 
solution $(2.5 \mu \mathrm{g} / \mathrm{mL})$ in phosphate-buffered saline (PBS; $10 \mathrm{mM}, \mathrm{pH} 7.2$ ), and the plates incubated at $4^{\circ} \mathrm{C}$ overnight. After three consecutive washes with $0.05 \%$ Tween-PBS, the plates were ready for use. Then, $100 \mu \mathrm{l}$ of the optimal dilution of each serum were added by duplicate to each well, and the plates incubated for 45 min at $37^{\circ} \mathrm{C}$. Optimal serum dilutions (assessed using 20 sera from culture positive and 20 sera from Brucella free animals belonging the different domestic animal species used as controls -see below-) in 0.05\% TweenPBS were $1 / 100$ (goats and phylogenetically related species) or $1 / 50$ (the remaining animal species tested). The non-reacting antibodies were removed by three consecutive washes with $0.05 \%$ Tween-PBS. Then, a conjugate solution containing $0.2 \mu \mathrm{g} / \mathrm{mL}$ of recombinant protein G/HRP (Pierce Chemical Co., Rockford, Ill, USA) in $0.05 \%$ Tween-PBS was added $(100 \mu \mathrm{l} /$ well $)$, and the plates incubated again for $45 \mathrm{~min}$ at $37^{\circ} \mathrm{C}$. After three consecutive washes with $0.05 \%$ Tween-PBS to remove unbound conjugate, the reaction was developed with $100 \mu \mathrm{l} /$ well of a $0.1 \%$ solution of 2,2 -azinobis, 3 -ethylbenzothiazoline sulfonic acid, diammonium salt (ABTS; Sigma Chemical Co., St. Louis, Mo., USA) and 0.004\% hydrogen peroxide in $0.05 \mathrm{M}$ citrate buffer $(\mathrm{pH} 4)$. The reaction was not stopped, and the OD at $405 \mathrm{~nm}$ was automatically assessed (Multiskan RC; Thermo Labsystems, Vantaa, Finland) after $15 \mathrm{~min}$ of incubation at room temperature in the dark. Results were expressed as the percentage of optical density (\%OD) using the formula $[\% \mathrm{OD}=100 \times$ mean OD of duplicated sample/mean OD of duplicate positive control]. Due to the lack of gold standard sera (i.e., taken from culture positive and brucellosis free animals) from the different wild ungulate species, the sera used for setting up and iELISA validation were from Brucella culture positive (CP) and Brucella-free (BF) phylogenetically related domestic animals. Cattle sera were used as reference for red, roe and fallow deer; goat sera for chamois and Iberian wild goat; sheep sera for mouflon and Barbary sheep; and pig sera for wild boar. All gold standard sera from domestic species were available at the serum collection of the CITA (Zaragoza, Spain). To establish the optimal test conditions (i.e., those allowing the maximum of separation of \%OD values between the infected and free populations) for each animal species, sera from $88 \mathrm{CP}$ and $88 \mathrm{BF}$ cattle, $88 \mathrm{CP}$ and $88 \mathrm{BF}$ sheep, 44 CP and $88 \mathrm{BF}$ goats and $62 \mathrm{CP}$ and $100 \mathrm{BF}$ pigs were used. The overall results were then submitted to ROC analyses (Medcalc. 9.2.1.0 software) and cut-offs resulting in $100 \%$ diagnostic specificity and the maximal diagnostic sensitivity for sheep, goats and cattle (50\%OD), and pigs (40\%OD), were selected to further assess the apparent prevalence in the corresponding phylogenetically wild animals tested.

\section{Bacteriological analysis and Brucella typing}

Necropsy samples (lymph nodes, spleen and/or sexual organs) from iELISA-positive animals (see Table 2 for precise numbers in each species) were submitted to bacteriological analysis. To assess the relative diagnostic specificity of the iELISA developed, similar necropsy samples taken from iELISA-negative animals (see Table 2) were also cultured. Briefly, each sample was surface decontaminated by immersion in ethanol and gentle burning, introduced in sterile bags, suspended in the minimal amount of sterile PBS required for adequate homogenisation, and then homogenised in a blender (Stomacher; Seward Medical, London, UK). Each homogenate was smeared onto at least two plates of both Farrell's and modified Thayer Martin's culture media [31]. After 5-7 days of incubation at $37^{\circ} \mathrm{C}$ in $10 \% \mathrm{CO}_{2}$ atmosphere, the resulting Brucella isolates were identified according to standard procedures [32].

Brucella field isolates were further analysed using both molecular and standard bacteriological procedures. Bacterial DNA was extracted using QIAamp DNA minikit (QIAGEN, Hamburg, Germany). For the identification and differentiation of Brucella species, the Bruce-ladder multiplex PCR was applied as described elsewhere [33]. To assess the precise biovar and the different haplotypes of $B$. suis biovar 2 strains isolated, a multiplex PCR [34] and PCR-RFLP of omp31, omp $2 a$ and $o m p 2 b$ genes $[35,36]$ were used. The corresponding biovars of the two $B$. melitensis and B. abortus strains isolated were identified by agglutination with monospecific $A$ and $M$ antisera, and growth patterns in culture media containing Thionine and Basic Fuchsin $(20 \mu \mathrm{g} / \mathrm{ml})$ after incubation with and without $\mathrm{CO}_{2}$ atmospheres [32].

\section{Statistical analyses}

We used Sterne's exact method (up to $\mathrm{N}=1,000$ ), or adjusted Wald method $(\mathrm{N}>1,000)$ to estimate apparent prevalence confidence intervals [37]. Apparent prevalence comparisons among categories were done with homogeneity tests. The Mantel test was used to assess the spatial association between brucellosis apparent prevalence in wild boar across different sampling sites. Calculations were done with the PASSAGE software [38].

Quantitative exploratory analysis of risk factors for brucellosis apparent prevalence was carried out at two different geographic scales (peninsular and regional) using two-stage analyses. First, the associations between all the hypothesized risk factors and apparent prevalence were analyzed using single factor generalized models. Factors that captured the effect of any set of highly correlated variables for which $\mathrm{P}<0.1$ were selected for inclusion in the multivariate models (Table 3 ). In a second step, the selected variables were then jointly evaluated in a multiple logistic model. The individual iELISA 
Table 3 Factors included in the analysis, indicating those significantly associated (excluding other highly correlated variables) with apparent prevalence of brucellosis at the Peninsular (GLZ, $P<0.1, N>2416$ ) and the regional (GLZ, $P$ $<0.1, \mathrm{~N}>460$ ) scales.

\begin{tabular}{|c|c|c|c|}
\hline \multicolumn{4}{|l|}{ Peninsular scale } \\
\hline Factor & Estimate & $\mathrm{N}$ & $P$ \\
\hline \multicolumn{4}{|c|}{ Significantly associated with prevalence (selected for the model): } \\
\hline Age class (1-4) & & 2416 & $<.0001$ \\
\hline Month (1-12) & & 4394 & $<.0001$ \\
\hline Annual rainfall & -0.00013 & 4079 & 0.0011 \\
\hline Cultivated lands & 0.000629 & 4079 & 0.0091 \\
\hline Non-irrigated cultures & 0.000908 & 4079 & 0.0181 \\
\hline Iberian hare habitat suitability & 0.000011 & 4019 & 0.0287 \\
\hline Road & 0.07015 & 4079 & 0.0386 \\
\hline Woodlands & $(-0.000644)$ & 4079 & 0.0529 \\
\hline Irrigated cultures & 0.001514 & 4079 & 0.0709 \\
\hline Urban & 0.00572 & 4079 & 0.0745 \\
\hline \multicolumn{4}{|l|}{ Not associated with prevalence (not selected): } \\
\hline \multicolumn{4}{|c|}{$\begin{array}{l}\text { Sex (1-2), wild boar management, European brown hare habitat suitability, irrigated fruit orchards, pastures, annual radiation, slope range, mean } \\
\text { slope, maximum slope, mean altitude, min. altitude, max. altitude, altitude range, annual temperature [69], annual temp. (min), annual temp. (max) }\end{array}$} \\
\hline \multicolumn{4}{|l|}{ Regional scale } \\
\hline Factor & Estimate: & $\mathrm{N}$ & $\mathrm{p}$ \\
\hline \multicolumn{4}{|l|}{ Selected: } \\
\hline Age class & & & 0.0001 \\
\hline Month (1-12) & & 505 & 0.0263 \\
\hline Iberian hare abundance (pellet FBII) & -177.415 & 460 & 0.0457 \\
\hline Mean open-air farm size (number of pigs) & 0.000213 & 500 & 0.0532 \\
\hline Number of pigs on open-air farms & 0.000209 & 500 & 0.0625 \\
\hline Number of pigs on open-air farms per square $\mathrm{Km}$ & 0.1253 & 500 & 0.0949 \\
\hline \multicolumn{4}{|l|}{ Not selected: } \\
\hline \multicolumn{4}{|c|}{$\begin{array}{l}\text { Sex, Iberian hare habitat suitability, wild rabbit abundance (pellet FBII), wild boar km abundance, wild boar spatial aggregation index (Z), wild boar } \\
\text { abundance (dropping FBII), red deer FBII, red deer density (distance estimates), wild boar FBII by feeding site and ha, wild boar FBII by watering site } \\
\text { and ha, annual temperature [69], mean slope, annual rainfall, annual radiation, mean altitude, sampling estate surface (Ha), type of population (open } \\
\text { fenced, farm), fencing, \% boundary fenced, riparian habitats, irrigated cultures, non-irrigated cultures, cultivated lands, woodlands, irrigated fruit } \\
\text { orchards, urban, tree diversity, grass cover, scrubland cover, pine woodlands, pastures, dehesa (savannah-like open oak woodlands), number of } \\
\text { Quercus trees/5 m, total woodlands, tree cover, soil cover, total wood+scrublands, Quercus spp. }>4 \text { m/5 m, cultures (\%), scrublands (\%), number of } \\
\text { waterholes, waterholes per Ha, wild boar supplemental feeding, wild boar feeding sites, wild boar feeders per Ha, deer feeding sites, goats per Ha, } \\
\text { cattle per Ha, sheep per Ha, number of pig farms in municipality, pig farms per Km², total pigs in municipality, total number of pigs in municipality } \\
\text { per Km², mean farm size (number of pigs), number of pigs on closed farms per Km², closed pig farms in municipality, closed pig farms per Km², } \\
\text { mean closed farm size, pigs on closed farms, open-air pig farms in municipality, open-air pig farms per Km². }\end{array}$} \\
\hline
\end{tabular}

Sampling season and sampling site were included as random factors.

result $(\mathrm{N}=3,883)$ was the response variable (binomial, i.e. antibody presence or absence). Since sampling across different populations was not homogeneous in relation to age and sex, statistical analyses were conducted at the individual level to control for them. Age was included as a continuous discrete explanatory variable and sex was included as a categorical binomial explanatory variable. We used a stepwise strategy to obtain the final model. Statistical significance was assumed wherever $\mathrm{P}<0.05$. We used the SAS statistical package.

In the Peninsular scale model we controlled for the effect of the Bio-region by including it as categorical random variable. Factors tested are listed in Table 3.

In the smaller geographical scale model (Ciudad Real province, Bio-region 3 ), we restricted our analysis to wild boar sampled on 20 sites, that were well characterized regarding habitat characteristics (e.g. estate-related environmental conditions, land cover and habitat structure) and relevant wildlife management factors such as fencing, supplemental feeding, watering sites, and estimated abundance [39]. The variables tested are shown in Table 3.

Hunting season (from 2000-2001 to 2008-2009) and sampling site were included as random factors in both models.

\section{Results}

\section{iELISA validation}

As an example of the iELISA validation procedure followed, the distribution of \%OD results obtained with the 


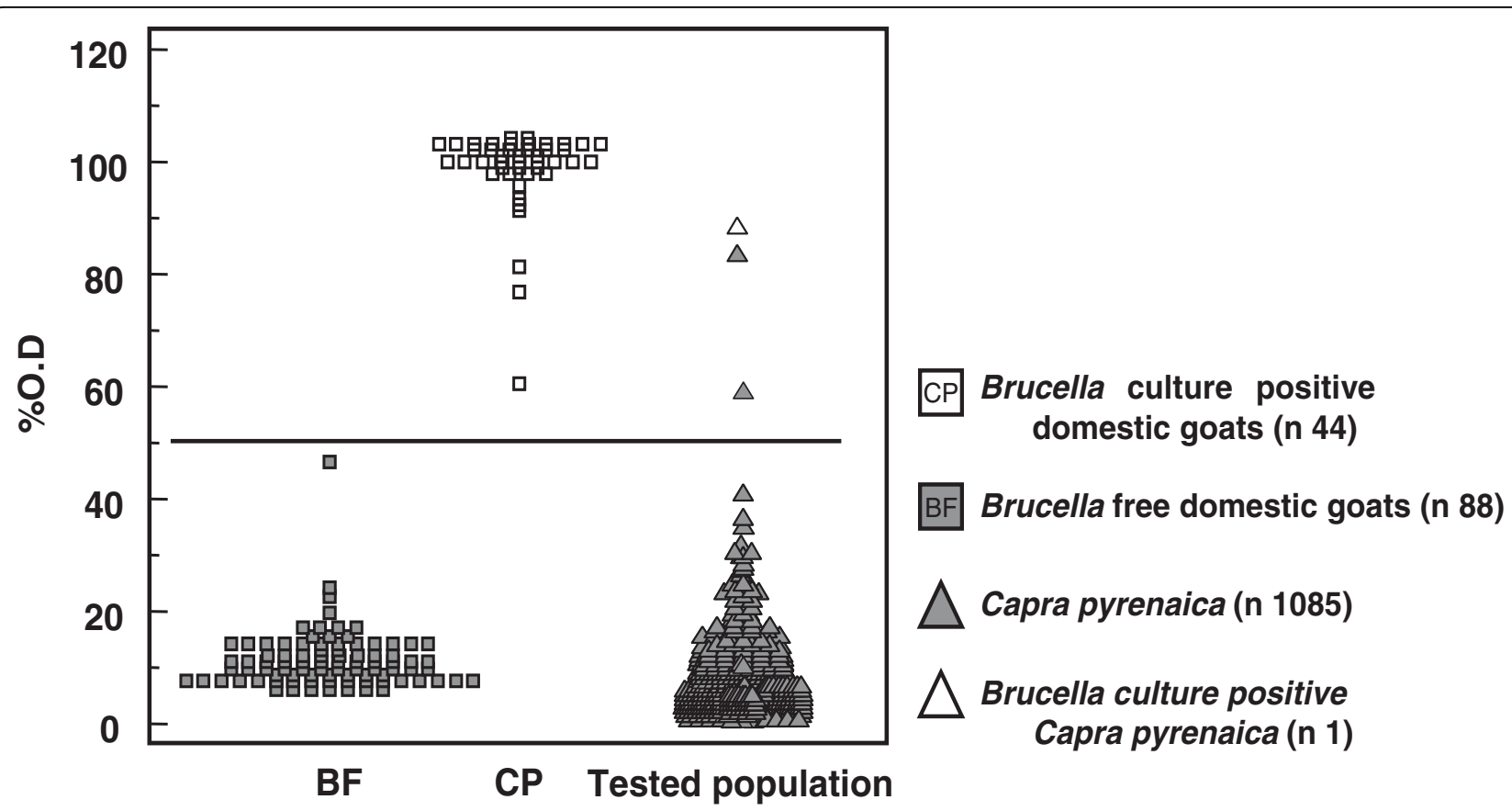

Figure 1 Example of the typical distribution of optical density (\% OD) results obtained by iELISA when testing the gold standard populations (from domestic goats) and its phylogenetically related Iberian wild goat (Capra pyrenaica) counterpart. The horizontal line represents the cut off selected for assessing the apparent prevalence of brucellosis.

gold standard populations in domestic goats and its phylogenetically related Capra pyrenaica counterpart is shown in Figure 1 . As seen in this figure, a relatively wide range of \% OD were resulting in $100 \%$ sensitivity and specificity with the gold standard populations tested, and this picture was similar when using gold standard sera from the cattle, sheep and pig populations used as reference controls. The corresponding cut-offs for the different wild animal species tested were $50 \%$ OD (for all wild ruminant species) and $40 \%$ OD (for wild boar), considering that the resulting sensitivity and specificity with the corresponding gold standard populations was always $100 \%$.

The relative specificity of the iELISA versus the culture results obtained with the 50 iELISA negative wild ruminants tested (Table 2) was adequate since no positive isolations were obtained in these animals. The relative specificity versus the culture results was also adequate in wild boar, since only one B. suis biovar 2 strain was isolated from the cultured specimens of the 50 iELISA negative animals tested.

\section{Studies in wild ruminant species}

Our results revealed no or only very limited antibody responses to infections by smooth Brucella species in Iberian wild ruminants (Table 2). Anti-Brucella antibodies were detected in chamois, red deer, and to a lesser extent, the Iberian wild goat. The highest apparent prevalence $(0.8 \%)$ was identified in chamois, being essentially detected in the animals living in the Pyrenean Mountains, in Bioregion 2 .

Altogether, the overall estimated apparent prevalence in wild ruminants was as low as $0.4 \%$ (95\% CI range 0.3 $0.6 \%$ ), and no significant inter-species differences (Chisquare $=10.2,6$ d.f., $\mathrm{P}>0.05$ ) or spatial aggregation (data not shown) were evidenced. However, slightly higher apparent prevalence was observed locally. As an example, the percentage of red deer positive reactors reached maximum value of $1.9 \%$ (3 out of 158 animals tested; $95 \% \mathrm{CI}$ 0.5-5.5) in the Garcipollera reserve (Pyrenees, Bio-region 2 ), and $0.8 \%$ (16 out of 1899 animals tested; range 0.5-1.4) in the Montes Universales reserve (Bio-region 4).

Only two out of the 93 animals submitted to bacteriological analyses (one from a clinical case, 42 from iELISApositive animals, and 50 from ELISA-negative animals, Table 2) resulted in Brucella positive culture. One of the strains identified (B. melitensis biovar 1) was isolated from the clinical case, a severely ill Iberian wild goat buck found in Albacete province (Bio-region 4), and that resulted positive in the iELISA. The other strain isolated (B. abortus biovar 1) came from a hunter-harvested red deer stag, from Montes Universales reserve in Teruel province (Bioregion 4), and found also positive in the iELISA.

\section{Studies in wild boar}

In strong contrast with results found in wild ruminants, wild boar showed a high apparent prevalence of 
brucellosis (33\%; 95\%CI 31.6-34.4; see also Additional file 1), in all Bio-regions tested (Figure 2 panel A). The highest apparent prevalence (average $46 \%$ with some populations reaching over $80 \%$ ) was found in Bio-region 3 (Figure 2 panel A). The remaining Bio-regions showed lower but still high values (average 26\%; Figure 2 panel A). No statistically significant spatial association was found by Mantel test (Pearson $\mathrm{r}=-0.10, \mathrm{~N}=68 ; \mathrm{P}=$ 0.99).

A total of 539 necropsy samples from iELISA positive wild boar were submitted to bacteriological culture (Table 2). One hundred and four isolates (representing $19.3 \%$ of the animals tested) were obtained from these seropositive animals cultured, while only 1 of the 50 iELISA negative wild boar tested resulted in positive culture, being this difference statistically significant $(\mathrm{P}<$ 0.001). All isolates were identified as Brucella suis, and the multiplex PCR identified patterns consistent with those characteristic of $B$. suis biovar 2. The PCR-RFLP of omp2a, omp $2 b$ and omp31 genes resulted in three different B. suis biovar 2 haplotypes (Figure 2 panel C). Type A strains $(\mathrm{N}=57)$ were found widely distributed throughout Bio-regions 1, 2 and 3, whereas type $\mathrm{C}(\mathrm{N}=$ 46) and $\mathrm{B}(\mathrm{N}=1)$ strains were restricted to Bio-regions 2 and 3, respectively (Figure 2 panel $\mathrm{B}$ ).

Table 4 shows the variables included in the final largescale model. The probability of wild boar testing positive in the iELISA was affected by age (Chi-square $=42.3,3$ d.f., $\mathrm{P}<0.001$; Figure 3 panel A), age-by-sex interaction, rainfall, Bio-region and month. By contrast, apparent prevalence was not affected by sex (males 35.8\%, 95\% CI 33.3-38.5; females 36.5\%, 95\%CI 34.0-39.0). Apparent prevalence increased during the hunting season reaching maximum levels in February (Figure 3 panel B). Apparent prevalence in wild boar also varied among Bioregions (Chi-square $=183$, 4 d.f., $\mathrm{P}<0.001$ ), Bio-region 3 showing almost the double of apparent prevalence than the other Bio-regions.

Table 5 shows the 6 variables included in the final regional-scale model. The probability of testing positive in the iELISA was affected by age-by-sex interaction, sampling month, and the number of open-air bred pigs per square $\mathrm{Km}$ in the sampling municipality. Fifty eight additional variables resulted not statistically significant in the first analysis and thus, not selected for the model (Table 3).

\section{Discussion}

We developed and validated a multi-species immunosorbent assay and applied it to determine the apparent prevalence and distribution of brucellosis in wild ungulates from the Iberian Peninsula. Our results showed that wild ruminants do not play a relevant role in the maintenance of $B$. abortus and B. melitensis infections. In contrast, the wild boar was identified as an important threat for B. suis infection.

The quality of the diagnostic methodology used is of paramount importance to assess the prevalence of wildlife diseases [28]. Due to the lack of brucellosis tests validated for wildlife species, the most recommendable approach for studies to determine brucellosis prevalence in wildlife should be based in the use of classical serological tests such as the Rose Bengal (RBT), which has been widely validated in the domestic animal species phylogenetically related with wild ungulates, and extensively used worldwide [40]. These classical tests, however, require samples of a very high quality to avoid haemolysis problems. However, gathering high quality serum samples devoid from haemolysis is frequently impossible in standard wildlife sampling procedures, particularly those based on hunted specimens. To circumvent this problem, many recent brucellosis studies in wildlife have been based on immunosorbent assays -ELISA- $[17,41,42]$. One of the advantages of this serological test is that the degree of haemolysis of the serum samples does not affect significantly the ELISA performance [43]. Due to the absence of specific conjugates against the immunoglobulin isotypes of the different wildlife species, indirect ELISAs have not been widely used, and most of studies have been based on the use of competitive ELISAs, which are potentially able to identify specific anti-Brucella antibodies in all animal species [28,44-46]. However, due to the absence of adequate gold standard sera, most studies in wildlife have been performed using the protocols (i.e., serum dilution, antigen concentration, cut-off, etc) as recommended by manufacturers in domestic livestock $[14,17,47]$, and therefore without adequate validation for the corresponding wild species tested. Moreover, the problem of the false-positive serological reactions induced by gram-negative bacteria sharing common epitopes with Brucella [48,49], is also an important issue to properly assess brucellosis prevalence. Hence, recent studies suggest the need for better diagnostic tools to obtain reliable results in serological studies on brucellosis in wildlife [17].

The best gold standard known in brucellosis diagnosis is the isolation of the bacteria. However, individual bacteriology is cumbersome, unpractical and very expensive to be used as the unique test to determine the prevalence of brucellosis in animal populations. Thus, the most recommendable approach is a combination of serological and bacteriological studies, such as those conducted here. We developed an iELISA using an antigen sharing the major common surface epitopes present in all smooth Brucella species [50,51], allowing the diagnosis of infections induced by $B$. abortus, B. melitensis and $B$. suis. The lack of availability of polyclonal or monoclonal antibodies raised to detect specifically the 


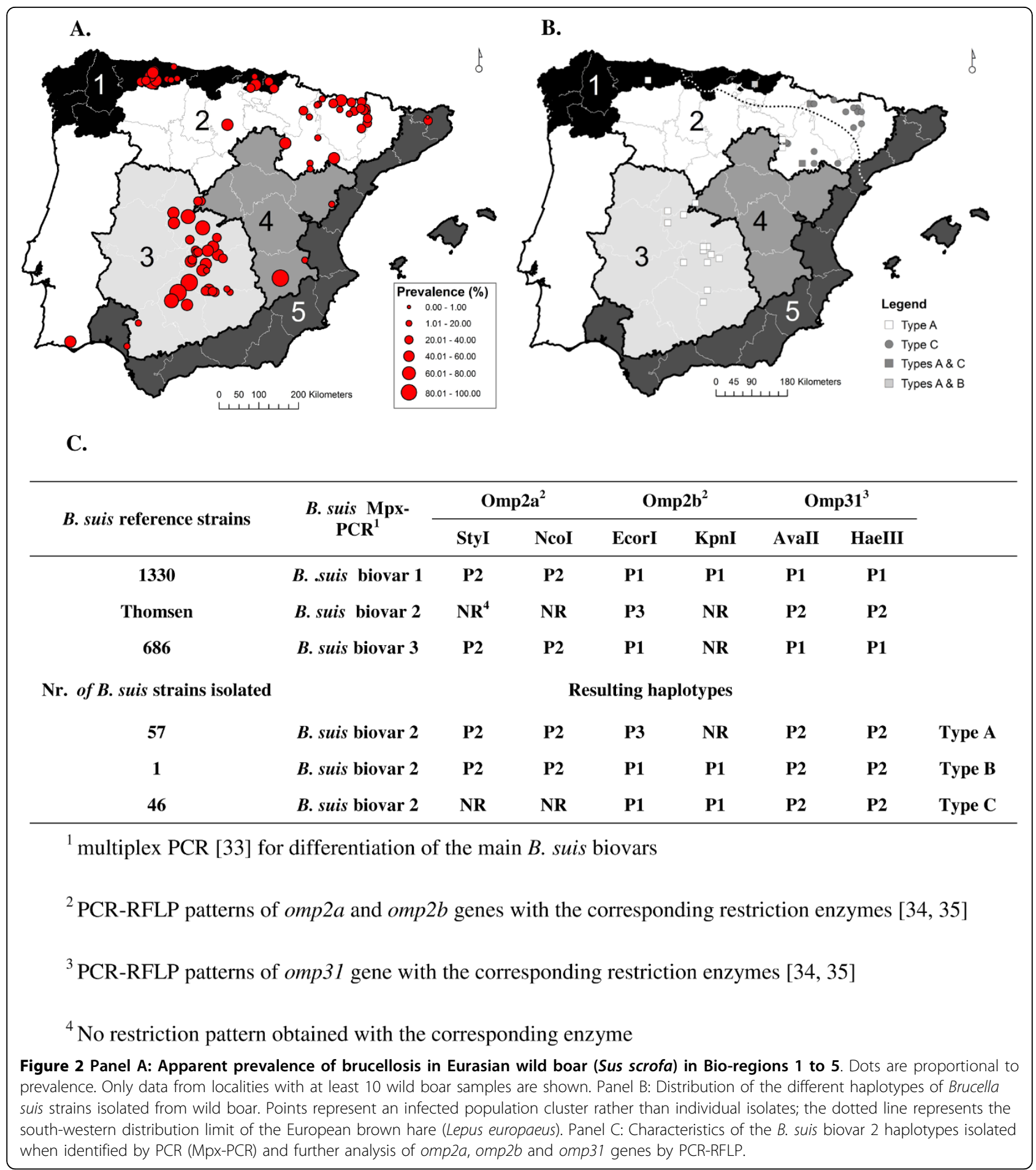

immunoglobulin isotypes of wildlife species was overcome by using protein $\mathrm{G}$ as a conjugate. This reagent has been reported suitable in wildlife for detecting antibodies to Brucella [52,53] and other pathogens [54,55]. Due to the absence of gold standard sera from culture positive and brucellosis free wild animals, we validated our iELISA using gold standard sera from the closest phylogenetically related domestic species. The adequate relative sensitivity of the iELISA with respect to the bacteriological status of the animals was confirmed in wild boar, in which the number of strains isolated from seropositive animals was relatively high (Table 2 ), being comparable to those obtained in similar studies conducted in the EU [52]. 
Table 4 Effects on the probability of testing positive to brucellosis at Peninsular scale.

\begin{tabular}{lccc}
\hline Effect & DF & $F$ & $\operatorname{Pr}>\mathrm{F}$ \\
\hline Age & 3.1947 & 23.2 & $<0.001$ \\
Sex by age interaction & 4.1886 & 2.53 & 0.0390 \\
Rainfall & 1.186 & 10.7 & 0.0013 \\
Bio-region & 4.207 & 10.7 & $<0.001$ \\
Month & 4.1557 & 2.80 & 0.0247
\end{tabular}

DF degrees of freedom; F test statistic; $\mathrm{Pr}>\mathrm{F}$ probability.
Table 5 Effects on the probability of testing positive to brucellosis at Regional scale.

\begin{tabular}{lccc}
\hline Effect & DF & $\mathrm{F}$ & $\mathrm{Pr}>\mathrm{F}$ \\
\hline Month & 6.373 & 2.39 & 0.0280 \\
Open-air pigs per square $\mathrm{km}$ & 1.136 & 3.29 & 0.0919 \\
Sex by age interaction & 5.48 & 4.90 & 0.0002 \\
\hline DF degrees of freedom; $\mathrm{F}$ test statistic; Pr $>$ F probability. &
\end{tabular}
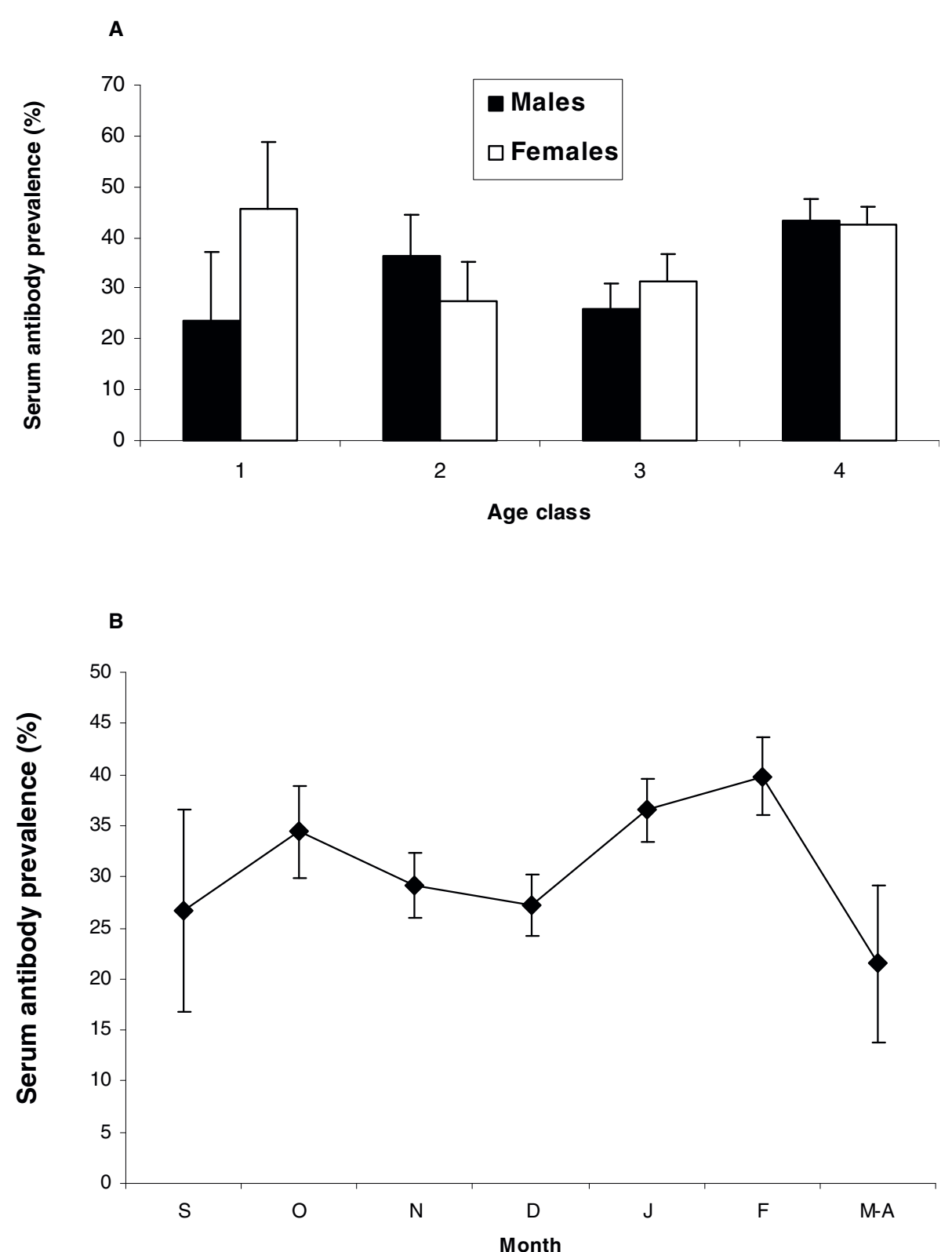

Figure 3 Distribution of apparent prevalence in wild boar (Sus scrofa) through age and sex classes (Panel A), and sampling period (Panel B) at the Peninsular scale. 
The success for bacteriological isolation depends on the quality of the samples cultured. Unfortunately, in our study it was not always possible to obtain necropsy samples of proper quality, which probably decreased the final sensitivity of the bacteriological methods applied. This can explain the relatively high number of samples from iELISA positive animals that resulted in negative culture. Moreover, the relative specificity of the iELISA versus culture results was also adequate since only one out of the 50 iELISA negative animals tested yielded a positive culture. However, this iELISA negative serum from an infected wild boar could also be due to a recent $B$. suis infection in which antibodies of the IgG isotypes (the only ones detected by protein $G$ ) had not yet been produced, or simply, as a consequence of a human error in sampling or identification.

The relative sensitivity of the iELISA developed could not be properly assessed in wild ruminants due to the low apparent prevalence figures detected and, accordingly, the low number of iELISA positive samples cultured (Table 2). The only two animals in which field Brucella strains were isolated resulted positive in the iELISA. Finally, no brucellae were isolated from the 50 iELISA negative wild ruminants tested, this result supporting the adequate relative specificity of the serological test developed. Therefore, this iELISA should be considered as adequate enough for detecting Brucella antibodies in the wild species studied.

At least for the species with large sampling sizes (Table 2), it can be concluded that wild ruminants are not a significant potential source of $B$. abortus and $B$. melitensis infections for livestock in the Iberian Peninsula. However, data on species with a limited sample size, such as Barbary sheep $(\mathrm{N}=8)$ and mouflon $(\mathrm{N}=$ $75)$, are not enough to support that general conclusion. The finding of the $B$. melitensis infected Iberian wild goat in a locality with no active sampling stresses, however, the importance of setting up passive wildlife surveillance networks.

The small variations in the geographical distribution of seropositive wild ruminants can reflect sampling biases rather than real differences in apparent prevalence. However, the relatively high apparent prevalence found in some areas could be also related with the high prevalence of brucellosis in domestic species reared in extensive breeding systems. As an example, the percentage of red deer and chamois positive reactors reached maximum values in some areas of the Pyrenees (Bioregion 2), and red deer in the Montes Universales reserve (Bio-region 4), that were coincident with some brucellosis outbreaks taking place in domestic sheep and cattle in these mountain areas during the 2002 and 2004 seasons (Gobierno de Aragón, Annual Animal Health Report, unpublished data).
Current knowledge on $B$. abortus epidemiology in the Yellowstone area strongly suggests that artificial management including crowding and supplemental feeding influences the dynamics of wildlife brucellosis [13]. The very low apparent prevalence of brucellosis in Iberian wild ruminants may be explained by a couple of nonmutually excluding hypotheses. First, the relatively low overall prevalence of brucellosis in domestic ruminants in Spain makes the transmission to wildlife highly improbable, despite the existence of important risk factors such as overabundance [27]. Second, artificial feeding in southern Spain takes place mostly in summer, once the lambing/calving season is over. Thus, abortions occurring at winter feeding sites as in elk in the Yellowstone area [13], are unlikely. This is consistent with recent results on the effects of management on elk behaviour and brucellosis transmission [56].

In strong contrast with the situation in wild ruminants, the wild boar population was found seriously affected by B. suis biovar 2 infection. The general apparent prevalence figures found herein (Table 2) were similar to those indicated in other European reports [10,14-17,57]. However, apparent prevalence close to $100 \%$ was recorded locally (Figure 2). Bio-region 3, the area where game is more intensively managed through fencing, feeding and translocation, was the region with the highest apparent prevalence (Figure 2 panel A). This Bio-region concentrates practically the whole Iberian censuses of domestic Iberian pigs reared in fully out door breeding systems.

The absence of sex effects on brucellosis apparent prevalence in wild boar (Table 3) was not surprising, since similar results have been found also in other diseases $[39,58]$. However, we found at both geographical scales a significant effect of the sex-by-age interaction on the apparent prevalence of brucellosis (Table 3 ). This effect can be explained by sex and age related differences in wild boar behaviour [59]. While females live in matriarchal groups, adult males live solitary and only contact with these matriarchal groups during the mating season [60]. Apparent prevalence observed among adult wild boar was higher than that found in younger age classes, as expected by the higher participation in reproduction by adults [61].

In wild boar, positivity to several other infectious agents has been linked with density, spatial aggregation or artificial management (e.g. Aujeszky's disease [61,62]; Bovine tuberculosis [39]; Porcine circovirus type 2 [58]). However, no relationship between apparent prevalence and wild boar management or density risk factors has been evidenced in this study. There is no clear explanation for this finding, and further research is needed to better identify the factors modulating B. suis infection.

Several authors have suggested that spillover from wild boar and European hares to domestic pigs could be 
a frequent event, and the explanation of the re-emergence of brucellosis due to B. suis biovar 2 in outdoor reared pigs in EU countries $[63,64]$. Historical contact between free ranging Iberian domestic pigs and wild boar could have boosted wild boar infection with $B$. suis biovar 2 in the Iberian Peninsula. As indicated above, Bio-region 3 is the Spanish region with more open-air bred domestic pigs [26], and in which the apparent prevalence figures in wild boar were maximal (Figure 2). In the small scale study carried out in this Bio-region 3, a positive relationship between apparent prevalence in wild boar and the density of open air bred Iberian pigs was evidenced (Table 5). This may contribute to explain the important prevalence of brucellosis reported in Iberian pig farms in the last years in Spain [24,65]. Accordingly, having in consideration the close genetic characteristics of the strains isolated in Spain [25], our study confirms that domestic Iberian pigs reared outdoor and wild boar share the same brucellosis infection due to $B$. suis biovar 2 . Three out of the five wild boar estates showing the highest apparent prevalence were fully open and sharing pastures with free-ranging domestic pigs.

In an attempt to further characterise the B. suis biovar 2 infection in wild boar, a DNA-based study was applied to all strains isolated (Figure 2 panel $C$ ). None of the three B. suis haplotypes identified (A, B and C; Figure 2 panel $C$ ) were coincident with the molecular patterns characteristic of the B. suis biovar 2 Thomsem reference strain (Figure 2 panel $C$ ). However, these three haplotypes were consistent with those previously identified in domestic pigs and wild boar in Spain, Portugal and other European countries [24,66]. The B. suis strains previously isolated from pigs and wild boar in the Iberian Peninsula corresponded exclusively to both A and B haplotypes, and with a neat predominance of type A (32 strains) versus type B (10 strains) [24]. In agreement with this, the type A strains isolated (57 strains) were largely predominant on type B (only one strain isolated) in our study (Figure 2, panel C), and were widely distributed in Bio-regions 1, 2 and 3 (Figure 2, panel B). The haplotype $C$ had never been reported previously in the Iberian Peninsula, but it has been reported in domestic pigs from France and Croatia and also in wild boar from France, Italy and Switzerland [24]. Surprisingly, this haplotype $\mathrm{C}$ was found in similar proportions as haplotype A (Figure 2, panel C). However, and interestingly, this haplotype was restricted exclusively to Bioregion 2 (Figure 2, panel B). This can explain the absence of previous reporting of this particular haplotype in Spain since none of the papers published were dealing with strains isolated from this Bio-region.

Altogether, it can be concluded that B. suis biovar 2 strains isolated from Iberian wild boar are spatially structured. This structuring was conserved despite frequent translocations taking place for hunting purposes [67].

In contrast with the situation reported in France [68], wild boar were capable to maintain B. suis biovar 2 infection independently of the existence of European brown hares. Interestingly, the unique $B$. suis biovar 2 strain isolated from European brown hare in Spain [25] was showing a molecular pattern different from the three haplotypes identified in this study in wild boar (J.M Blasco, unpublished results). This hare strain was showing also different restriction patterns from those identified in the $B$. suis biovar 2 Thomsen reference strain and other $B$. suis biovar 2 strains isolated from hares in France, which show common patterns with those identified in wild boar (B. Garin-Bastuji, personal communication). This suggests that at least in Spain, the B. suis biovar 2 haplotypes infecting European brown hares and wild boar may be different. However, this must be confirmed in further studies using larger numbers of animals. The possible role of the Iberian hare (Lepus granatensis) in B. suis biovar 2 epidemiology is currently unknown. No isolation of $B$. suis biovar 2 has been reported in Iberian hares but no adequate studies are available. Suitability of Iberian hare habitat, meaning open, flat, sparsely-forested Mediterranean agrosystems, was selected in the first step of the analysis, but not in the final model. Its weak link with wild boar apparent prevalence may be due to a correlation between Iberian hare habitat suitability and Bio-region 3. A similar explanation can be given for the inclusion of rainfall in the large-scale model, having in consideration that rainfall is more abundant in the North (e.g. Bio-region 1) than in Bio-region 3 (Table 1).

Data provided herein suggest that B. suis biovar 2 infection can be maintained in wild boar in an independent epidemiological cycle to that taking place in domestic pigs. The period of the year (month of sampling) was a significant factor affecting apparent prevalence (Tables 4,5 ), suggesting that the reproductive season may influence brucellosis spreading among wild boar. An alternative explanation could be related with differences in host-specific behaviour, for example regarding carrion consumption from gut piles during the hunting season (October to February).

\section{Conclusions}

In summary, we conclude that free-living wild ruminants are not a significant brucellosis reservoir in the Iberian Peninsula but conversely, wild boar is an important threat regarding $B$. suis biovar 2 infection. This represents an important hazard particularly for the Iberian pig population reared in out door breeding systems, but the entry of the disease in the highly intensified pig 
industry should not be disregarded. This situation could become of great concern if brucellosis control programs in domestic pigs are envisaged.

\section{Additional file 1: Detailed wild boar Brucella antibody}

seroprevalence by Bio-region. Data shows sample size, number of ELISA positive samples, and serum antibody prevalence of wild boar from the Iberian Peninsula.

Click here for file

[http://www.biomedcentral.com/content/supplementary/1471-2334-1046-S1.DOC]

\section{Acknowledgements}

Many colleagues at IREC, UNIZAR, NEIKER and SERIDA helped in field and laboratory. This is a contribution to the MCINN Plan Nacional research grant AGL2005-07401 on shared diseases and FEDER. The study benefited from agreements of IREC with MARM-OAPN, Castilla - La Mancha and Principado de Asturias. Additional support to the IREC is acknowledged to FISCAM (GC05-006 and PI-2007/56). CITA and UNIZAR also acknowledge support from INIA (FAU2008-00015). We acknowledge the dedicated assistance of the game wardens of Aragon and Asturias. The Aragon Government has financed part of this work under the programme "Health status surveillance on game wildlife in Aragon". NEIKER thanks the funding of the Department for Environment, Spatial Planning, Agriculture and Fisheries of the Basque Government and the collaboration of ACCA and Regional Governments. Grant and postdoctoral contract acknowledgements: P.M Muñoz (CITA Technologist grant and Juan de la Cierva research contract), M. Boadella (PhD grant TB-STEP, FP7). P. Acevedo (Juan de la Cierva research contract, MICINN and FEDER, project CGL2006-09567/BO). F. Ruiz-Fons (I.S. Carlos III research contract, Spanish Ministry of Health). The experiments and procedures included in this study comply with national laws.

\section{Author details}

'Centro de Investigación y Tecnología Agroalimentaria del Gobierno de Aragón (CITA). Montañana, 930 50059, Zaragoza. Spain. ${ }^{2}$ Instituto de Agrobiotecnología CSIC-UPNA-Gobierno de Navarra, 31192 Mutilva Baja, Spain. ${ }^{3}$ IREC (CSIC-UCLM-JCCM). Ronda de Toledo s/n, 13071 Ciudad Real, Spain. ${ }^{4}$ Departamento de Patología Animal de la Universidad de Zaragoza. Miguel Servet, 177 50013, Zaragoza, Spain. ${ }^{5}$ Biogeography, Diversity, and Conservation Research Team, Animal Biology, Department of Sciences, University of Malaga, E-29071 Málaga, Spain. ${ }^{6}$ SERIDA, Servicio Regional de Investigación y Desarrollo Agroalimentario, Laboratorio de Sanidad Animal, 33299 Jove, Gijón, Spain. ${ }^{7}$ NEIKER-TECNALIA, Inst Vasco Invest \& Desarrollo Agrario, Dpt Anim Hlth, Bizkaia 48160, Spain. ${ }^{8}$ Department of Veterinary Pathobiology, Center for Veterinary Health Sciences, Oklahoma State University, Stillwater, OK 74078, USA.

\section{Authors' contributions}

Conceived and designed the study: CG, JB, JF, JV, MB. Participated in sampling and field work: MB, MA, JV, PA, AO, FR, DF, MP. Carried out the laboratory work: PM, MR, DM, CM, MoB. Analyzed the data: MB, JV, PA, CG. Drafted the manuscript: PM, MB, JB, CG. All authors read and approved the final manuscript.

\section{Competing interests}

The authors declare that they have no competing interests.

Received: 5 August 2009

Accepted: 5 March 2010 Published: 5 March 2010

\section{References}

1. Cutler SJ, Whatmore AM, Commander AJ: Brucellosis, new aspects of an old disease. J Appl Microbiol 2005, 98:1270-1281.

2. Teyssou R, Morvan J, Leleu JP, Roumegou P, Goullin B, Carteron B: About a case of Human brucellosis due to Brucella suis biovar-2. Medecine Et Maladies Infectieuses 1989, 19:160-161.
3. Godfroid J, Cloeckaert A, Liautard JP, Kohler S, Fretin D, Walravens K, GarinBastuji B, Letesson JJ: From the discovery of the Malta fever's agent to the discovery of a marine mammal reservoir, brucellosis has continuously been a re-emerging zoonosis. Vet Res 2005, 36:313-326.

4. Scholz HC, Hubalek Z, Sedlacek I, Vergnaud G, Tomaso H, Al Dahouk S, Melzer F, Kampfer P, Neubauer H, Cloeckaert A, Maquart M, Zygmunt MS, Whatmore AM, Falsen E, Bahn P, Gollner C, Pfeffer M, Huber B, Busse H-J, Nockler K: Brucella microti sp. nov., isolated from the common vole Microtus arvalis. Int I Syst Evol Microbiol 2008, 58:375-382.

5. Tryland M, Kleivane L, Alfredsson A, Kjeld M, Arnason A, Stuen S, Godfroid J: Evidence of Brucella infection in marine mammals in the North Atlantic Ocean. Vet Rec 1999, 144:588-592.

6. Ferroglio E, Tolari F, Bollo E, Bassano B: Isolation of Brucella melitensis From Alpine Ibex. J Wildl Dis 1998, 34:400-402.

7. Garin-Bastuji B, Oudar J, Richard Y, Gastellu J: Isolation of B. melitensis Biovar 3 From a Chamois (Rupicabra rupicabra) In The Southern French Alps. J Wildl Dis 1990, 26:116-118.

8. Gortazar C, Ferroglio E, Hofle U, Frolich K, Vicente J: Diseases shared between wildlife and livestock: a European perspective. Eur J Wild Res 2007, 53:241-256.

9. Gaffuri A, Giacometti M, Tranquillo VM, Magnino S, Cordioli P, Lanfranchi P: Serosurvey of roe deer, chamois and domestic sheep in the central Italian Alps. J Wildl Dis 2006, 42:685-690.

10. Garin-Bastuji B, Delcueillerie F: Human and animal brucellosis in France in 2000. Epidemiological situation - Control and eradication programmes. Les brucelloses humaine et animale en france en l'an 2000 Situation épidémiologique - Programmes de contrôle et d'éradication 2001, 31:202-216.

11. Conner MM, Ebinger MR, Blanchong JA, Cross PC: Infectious disease in cervids of North America: data, models, and management challenges. Ann N Y Acad Sci 2008, 1134:146-172.

12. Etter RP, Drew ML: Brucellosis in elk of eastern Idaho. J Wild Dis 2006, 42:271-278.

13. Cross PC, Edwards WH, Scurlock BM, Maichak EJ, Rogerson JD: Effects of management and climate on elk brucellosis in the Greater Yellowstone Ecosystem. Ecol Appl 2007, 17:957-964.

14. Al Dahouk S, Nockler K, Tomaso H, Splettstoesser WD, Jungersen G, Riber U, Petry T, Hoffmann D, Scholz HC, Hensel A, Neubauer H: Seroprevalence of brucellosis, tularemia, and yersiniosis in wild boars (Sus scrofa) from North-Eastern Germany. J Vet Med Ser B-Infect Dis Vet Public Health 2005, 52:444-455.

15. Cvetnic Z, Mitak M, Ocepek M, Lojkic M, Terzic S, Jemersic L, Humski A, Habrun B, Sostaric B, Brstilo M, Krt B, Garin-Bastuji B: Wild boars (Sus scrofa) as reservoirs of Brucella suis biovar 2 in Croatia. Acta Vet Hung 2003, 51:465-473.

16. Hubálek Z, Treml F, Juricova Z, Hunady M, Halouzka J, Janik V, Bill D: Serological survey of the wild boar (Sus scrofa) for tularaemia and brucellosis in South Moravia, Czech Republic. Veterinarni Medicina 2002, 47:60-66.

17. Koppel C, Knopf L, Ryser MP, Miserez R, Thur B, Stark KDC: Serosurveillance for selected infectious disease agents in wild boars (Sus scrofa) and outdoor pigs in Switzerland. Eur J Wildl Res 2007, 53:212-220.

18. Bergagna S, Zoppi S, Ferroglio E, Gobetto M, Dondo A, Giannatale ED, Gennero MS, Grattarola C: Epidemiologic Survey for Brucella suis Biovar 2 in a Wild Boar (Sus scrofa) Population in Northwest Italy. J Wildl Dis 2009, 45:1178-1181.

19. Pikula J, Beklova M, Holesovska Z, Skocovska B, Treml F: Ecology of brucellosis of the European hare in the Czech Republic. Veterinarni Medicina 2005, 50:105-109.

20. Drew ML, Jessup DA, Burr AA, Franti CE: Serological survey for brucellosis in feral swine, wild ruminants, and black bear of California, 1977 to 1989. J Wildl Dis 1992, 28:355-363.

21. Candela MG, Serrano E, Martinez-Carrasco C, Martín-Atance P, Cubero MJ, Alonso F, Leon L: Diseases coinfection is an important factor in epidemiological studies: the first serosurvey of the aoudad (Ammotragus lervia). Eur J Clin Microbiol Infect 2008, 1-9.

22. Falconi C, Oleaga A, López-Olvera JR, Casais R, Prieto M, Gortázar C: Prevalence of antibodies against selected agents shared between Cantabrian chamois (Rupicapra pyrenaica parva) and domestic goats. Eur J Wildl Res 2009, 1-7.

23. López-Olvera JR, Vidal D, Vicente J, Pérez M, Luján L, Gortázar CE: Serological survey of selected infectious diseases in mouflon (Ovis 
aries musimon) from south-central Spain. Eur J Wildl Res 2009, 55:75-79.

24. Garcia-Yoldi D, Le Fleche P, De Miguel MJ, Munoz PM, Blasco JM, Cvetnic Z, Marín CM, Vergnaud G, Lopez-Goñi I: Comparison of multiplelocus variable-number tandem-repeat analysis with other PCR-based methods for typing Brucella suis isolates. J Clin Microbiol 2007, 45:4070-4072.

25. Lavín S, Blasco JM, Velarde R, Mentaberre G, Casas E, Marco I: Descripción del primer caso de Brucelosis en la liebre europea (Lepus aeuropaeus) en la Península Ibérica. Información Veterinaria 2006, 18-21.

26. Gortazar C, Herrero J, Villafuerte R, Marco J: Historical examination of the status of large mammals in Aragon, Spain. Mammalia 2000, 64:411-422.

27. Gortazar C, Acevedo P, Ruiz-Fons F, Vicente J: Disease risks and overabundance of game species. Eur J Wildl Res 2006, 52:81-87.

28. Van Houten CKJ, Lee Belden E, Kreeger TJ, Williams ES, Edwards WH, Thorne ET, Cook WE, Mills KW: Validation of a Brucella abortus competitive enzyme-linked immunosorbent assay for use in Rocky Mountain elk (Cervus elaphus nelsoni). J Wildl Dis 2003, 39:316-322.

29. Saenz de Buruaga M, Lucio AJ, Purroy J: Reconocimiento de sexo y edad en especies cinegéticas. Vitoria, Spain: Diputación Foral de Álava 1991.

30. Leong D, Diaz R, Milner K, Rudbach J, Wilson JB: Some Structural and Biological Properties of Brucella Endotoxin. Infection Immunity 1970, 1:174-182.

31. Marín CM, Jiménez-De-Bagüés MP, Barberán M, Blasco JM: Comparison of two selective media for the isolation of Brucella melitensis from naturally infected sheep and goats. Vet Rec 1996, 138:409-411.

32. Alton $\mathrm{GG}$, Jones $\mathrm{LM}$, Angus RD, Verger JM: Techniques for the brucellosis laboratory. Paris: Institute National de la Reserche Agronomic (INRA) 1988.

33. Garcia-Yoldi D, Marín CM, de Miguel MJ, Munoz PM, Vizmanos JL, LopezGoñi I: Multiplex PCR assay for the identification and differentiation of all Brucella species and the vaccine strains Brucella abortus S19 and RB51 and Brucella melitensis Rev1. Clin Chem 2006, 52:779-781.

34. Garcia-Yoldi D: Tipificación molecular de Brucella y aplicación de la PCR al diagnóstico de la brucelosis. Veterinary Medicine thesis Universidad de Navarra, Pamplona, Spain: Universidad de Navarra 2008.

35. Cloeckaert A, Verger JM, Grayon M, Grepinet O: Restriction Site Polymorphism of the Genes Encoding the Major $25 \mathrm{Kda}$ and $36 \mathrm{Kda}$ Outer-Membrane Proteins of Brucella. Microbiology 1995, 141:2111-2121.

36. Vizcaíno N, Verger JM, Grayon M, Zygmunt MS, Cloeckaert A: DNA polymorphism at the Omp-31 locus of Brucella Spp - evidence for a large deletion in Brucella abortu s, and other species-specific markers. Microbiology 1997, 143:2913-2921.

37. Reiczigel J: Confidence intervals for the binomial parameter: some new considerations. Stat Med 2003, 22:611-621.

38. Rosenberg MS: PASSAGE Pattern Analysis, Spatial Statistics, and Geographic Exegesis Version 11 Department of Biology, Arizona State University, Tempe, AZ 2001.

39. Vicente J, Hofle U, Garrido JM, Fernandez-de-Mera IG, Acevedo P, Juste R, Barral M, Gortazar C: Risk factors associated with the prevalence of tuberculosis-like lesions in fenced wild boar and red deer in south central Spain. Vet Res 2007, 38:451-464

40. OIE: Porcine Brucellosis. Manual of Diagnostic Tests and Vaccines for Terrestrial Animals 2009, 1108-1114.

41. Cvetnic Z, Toncic J, Spicic S, Lojkic M, Terzic S, Jemersic L, Humski A, Curic S, Mitak M, Habrun B, Brstilo M, Ocepek M, Krt B: Brucellosis in wild boar (Sus scrofa) in the Republic of Croatia. Veterinarni Medicina 2004, 49:115-122.

42. Zarnke RL, Saliki JT, Macmillan AP, Brew SD, Dawson CE, Ver Hoef JM, Frost KJ, Small RJ: Serologic survey for Brucella spp., phocid herpesvirus-1, phocid herpesvirus-2, and phocine distemper virus in harbor seals from Alaska, 1976-1999. J Wildl Dis 2006, 42:290-300.

43. Neumann EJ, Bonistalli KN: Effect of blood sample handling postcollection on Erysipelothrix rhusiopathiae antibody titres. Vet J 2009, 180:325-329.

44. Gall D, Nielsen K, Forbes L, Davis D, Elzer P, Olsen S, Balsevicius S, Kelly L, Smith $P$, Tan S, Joly D: Validation of the fluorescence polarization assay and comparison to other serological assays for the detection of serum antibodies to Brucella abortus in bison. J Wildl Dis 2000, 36:469-476.

45. Nielsen O, Stewart REA, Nielsen K, Measures L, Duignan P: Serologic survey of Brucella spp. antibodies in some marine mammals of North America. J Wildl Dis 2001, 37:89-100.
46. Van Bressem ME, Van Waerebeek K, Raga JA, Godfroid J, Brew SD, MacMillan AP: Serological evidence of Brucella species infection in odontocetes from the south Pacific and the Mediterranean. Vet Rec 2001, 148:657-661.

47. Deem SL, Noss AJ, Villarroel R, Uhart MM, Karesh WB: Disease Survey of Free-ranging Grey Brocket Deer (Mazama gouazoubira) in the Gran Chaco, Bolivia. J Wildl Dis 2004, 40:92-98.

48. Kittelberger R, Reichel MP, Joyce MA, Staak C: Serological cross-reactivity between Brucella abortus and Yersinia enterocolitica 0/9: 3. Specificity of the in-vitro antigen-specific gamma interferon test for Bovine brucellosis. Diagnosis in experimentally Yersinia enterocolitica 0/9Infected cattle. Vet Microbiol 1997, 57:361-371.

49. Muñoz PM, Marín CM, Monreal D, Gonzalez D, Garin-Bastuji B, Diaz R, Mainar-Jaime RC, Moriyon I, Blasco JM: Efficacy of several serological tests and antigens for diagnosis of bovine brucellosis in the presence of false-positive serological results due to Yersinia enterocolitica 0:9. Clin Diagn Lab Immun 2005, 12:141-151.

50. Alton GG: Brucella suis. Animal Brucellosis Boston: CRC PressNielsen K, Duncan J 1990, 412-422.

51. Cherwonogrodzky JW, Dubray G, Moreno E, Mayer H: Antigens of Brucella. Animal Brucellosis CRC PressNielssen K, Duncan JR 1990, 19-64.

52. Godfroid J, Michel P, Uytterhaegen L, Desmedt C, Rasseneur F, Boelaert F, Saegerman C, Patigny X: Brucella suis biotipe 2 infection of wild boars (Sus scrofa) in Belgium. Ann Med Vet 1994, 138:263-268.

53. Nielsen $K$, Smitha P, Yua W, Nicolettib P, Elzerc P, Viglioccod A, Silvad P, Bermudeze R, Renteriae T, Morenoe F, Ruizf A, Massengillg C, Muenksg Q, Kennyh K, Tollersrudi T, Samartinoj L, Condej S, Draghi de Benitezk G, Galla D, Perezl B, Rojasm X: Enzyme immunoassay for the diagnosis of brucellosis: chimeric Protein A-Protein $G$ as a common enzyme labeled detection reagent for sera for different animal species. Vet Microbiol 2004, 101:123-129.

54. Reyes-Garcia R, Perez-de-la-Lastra JM, Vicente J, Ruiz-Fons F, Garrido JM, Gortazar C: Large-scale ELISA testing of Spanish red deer for paratuberculosis. Vet Immunol Immunopathol 2008, 124:75-81.

55. Aurtenetxe O, Barral M, Vicente J, de la Fuente J, Gortazar C, Juste RA: Development and validation of an enzyme-linked immunosorbent assay for antibodies against Mycobacterium bovis in European wild boar. BMC Vet Res 2008, 4:43.

56. Maichak EJ, Scurlock BM, Rogerson JD, Meadows LL, Barbknecht AE, Edwards WH, Cross PC: Effects of management, behavior and scavening on risk of Brucellosis transmission in elk of western Wyoming. J Wildl Dis 2009, 45(2):398-410.

57. Dedek J, Löpelmann H, Natterman A: Serologische Untersuchungen auf Brucellose und Tularämie beim Schwarzwild. Mh Vet -Med 1986, 41:150-153.

58. Vicente J, Segales J, Hofle U, Balasch M, Plana-Duran J, Domingo M, Gortazar C: Epidemiological study on porcine circovirus type 2 (PCV2) infection in the European wild boar (Sus scrofa). Vet Res 2004, 35:243-253.

59. Ruiz-Fons F, Vidal D, Vicente J, Acevedo P, Fernandez-de-Mera IG, Montoro V, Gortazar C: Epidemiological risk factors of Aujeszky's disease in wild boars (Sus scrofa) and domestic pigs in Spain. Eur J Wildl Res 2008, 54:549-555.

60. Rosell C, Herrero J: Sus scrofa. Atlas de los mamíferos terrestres de España Madrid: Dirección General de la Conservación de la Naturaleza-SECEMSECEMUPalomo LJ, Gisbert J 2002.

61. Ruiz-Fons F, Vidal D, Hofle U, Vicente J, Gortazar C: Aujeszky's disease virus infection patterns in European wild boar. Vet microbiol 2007, 120:241-250.

62. Vicente J, Ruiz-Fons F, Vidal D, Hofle U, Acevedo P, Villanua D, FernandezDe-Mera IG, Martin MP, Gortazar C: Serosurvey of Aujeszky's disease virus infection in European wild boar in Spain. Vet Rec 2005, 156:408-412.

63. Godfroid J, Kasbohrer A: Brucellosis in the European Union and Norway at the turn of the twenty-first century. Vet Microbiol 2002, 90:135-145.

64. Leuenberger R, Boujon P, Thur B, Miserez R, Garin-Bastuji B, Rufenacht J, Stark KDC: Prevalence of classical swine fever, Aujeszky's disease and brucellosis in a population of wild boar in Switzerland. Vet Rec 2007, 160:362-368

65. Muñoz PM, DeMiguel MJ, Blasco JM, Marín CM: Porcine brucellosis in Spain: serological and bacteriological study of 11 outbreaks. $X$ Jornadas sobre Producción Animal: 2003; Zaragoza 2003, 417-419.

66. Ferrao-Beck L, Cardoso R, Muñoz PM, de Miguel MJ, Albert D, Ferreira AC, Marín CM, Thiebaud M, Jacques I, Grayon M, Zygmunt MS, Garin-Bastuji B, 
Blasco JM, Sa MI: Development of a multiplex PCR assay for polymorphism analysis of Brucella suis biovars causing brucellosis in swine. Vet Microbiol 2006, 115:269-277.

67. Soriguer RC, Márquez FJ, Pérez JM: Las translocaciones (introducciones y reintroducciones) de especies cinegéticas y sus efectos medioambientales. Galemys 1998, 10:19-35.

68. Garin-Bastuji B, Vaillant V, Albert D, Tourrand B, Danjean MP, Lagier A, Rispal P, Benquet B, Maurin M, De Valk $H$, Mailles A: Is brucellosis due the biovar 2 of Brucella suis an emerging zoonosis in France? Two case reports in wild boar and hare hunters. Proceedings of the International Society of Chemotherapy Disease Management Meeting, 1st International Meeting on Treatment of Human Brucellosis: 2006; Loannina, Greece 2006.

69. Jothikumar N, Cromeans TL, Robertson BH, Meng XJ, Hill VR: A broadly reactive one-step real-time RT-PCR assay for rapid and sensitive detection of hepatitis E virus. J Virol Methods 2006, 131:65-71.

\section{Pre-publication history}

The pre-publication history for this paper can be accessed here:http://www. biomedcentral.com/1471-2334/10/46/prepub

doi:10.1186/1471-2334-10-46

Cite this article as: Muñoz et al: Spatial distribution and risk factors of Brucellosis in Iberian wild ungulates. BMC Infectious Diseases 2010 10:46.

\section{Submit your next manuscript to BioMed Central} and take full advantage of:

- Convenient online submission

- Thorough peer review

- No space constraints or color figure charges

- Immediate publication on acceptance

- Inclusion in PubMed, CAS, Scopus and Google Scholar

- Research which is freely available for redistribution

Submit your manuscript at www.biomedcentral.com/submit 